\title{
The Expansion of the English Language Across Turkey: Threat or Opportunity?
}

\author{
Türkiye Genelinde İngiliz Dilinin Yaygınlaşması: \\ Tehlike mi yoksa Fırsat mı?
}

\begin{abstract}
Ali KARAKAȘ ${ }^{*}$
Abstract: The purpose of this paper is to discuss and report on the spread of the English language across Turkey, and how people from different camps in the country show reactions to its current place. In this sense, with an eye to projecting how a welcoming atmosphere has chronologically occurred in Turkey for English to gain importance as an inescapable phenomenon, brief information on the country profile is given to the reader before the main discussion. To achieve the purpose of the paper, the discussions within the main body of the paper are grounded on the conceptual framework of language spread and its two sub-divisions: planned and unplanned language spread. The current place of English in Turkey is described based on four main domains and their sub-domains. These domains include the presence of English in scientific research and communication, in the workplace, in cultural products and the media and finally in education. For each specific domain, a small amount of space is allowed to cite people's reactions to the omnipresence of English, including both their concerns and positive remarks regarding the issue. The paper concludes that the spread of English in Turkey creates dilemmas among people and for the state, and no easy solution is seen in the immediate future in regard to the expansion of English.
\end{abstract}

Keywords: English, language spread, planned spread, unplanned spread, Turkey

Özet: Bu çalışmanın amacı İngiliz dilinin Türkiye’deki yaygınlaşmasını ve bu yaygınlaşma karşısında ülkedeki farklı görüş ve sosyal tabakadan insanların bu yaygınlaşmaya karşı gösterdikleri tepkileri ele almak ve aktarmaktır. Bu bağlamda Türkiye'de kaçınılmaz bir olgu olarak önem kazanan İngilizce’ye karşı nasıl davetkâr bir ortamın oluştuğunu göstermek amacıyla ana tartışmadan önce okuyucuya ülke özgeçmişi hakkında kısa bilgiler sunulmaktadır. Çalışmanın amacını gerçekleştirmek için çalışmanın ana bölümlerindeki tartışmalar dil yayılımı ve dil yayılımının altbölümleri olan planlı ve plansız dil yayılımı kuramsal çerçevesinde ele alınmıştır. İngilizce'nin Türkiye'deki şu anki mevcut konumu dört ana ilgi alanı ve çeşitli alt alanlara dayanılarak betimlenmektedir. Bu alanlar İngilizce'nin bilimsel araştırma ve iletişimde, iş yerinde, kültürel ürünlerde ve medyada ve son olarak da eğitimdeki varoluşunu içermektedir. Her bir alt alan için çalışmada küçük bir bölüm insanların İngilizce’nin her yerde bulunmasına yönelik hem kaygılarını hem de olumlu ifadelerini içeren tepkilerini göstermeye ayrılmıştır. Çalışmada İngilizce'nin Türkiye'de yayılımının insanlar arasında ve devlet için ikilemelere yol açtığı ve İngilizce’nin yaygınlaşması konusunda bu kaygılar karşısında kolay bir çözümün yakın bir süreçte görünmediği sonucuna varılmıştır.

Anahtar sözcükler: İngilizce, dil yayılımı, planlı yayılım, plansız yayılım, Türkiye

\footnotetext{
* PhD. Candidate, University of Southampton, Modern Languages, Southampton, UK, ak16g11@soton.ac.uk
} 


\section{Introduction}

There is no doubt that English is currently the most widely and chiefly used language in both international and intra-national arenas for a variety of purposes. It is also regarded as the global lingua franca of our age, connecting people from different corners of the globe. According to the statistics cited by Crystal $(2003,6)$, “about a quarter of the world's population is already fluent or competent in English, and this figure is steadily growing", which clearly demonstrates that English is rapidly being spread across the continents and gaining acceptance in numerous countries with different statuses. That's why, as "English spreads, speakers [and users] morph it into the world tongue" (Rohde, 2003). As once Nokia propagated itself as "connecting people', this function now is fulfilled by the English language. Therefore, English enjoys such a significant status that no countries can remain indifferent to its ubiquity anymore. Turkey is one of those countries having attached and still attaching prime importance to English and is attempting to draw advantages from it in various domains within the country and beyond her boundaries.

The position and spread of English in Turkey has long been a focus for many researchers at regular intervals with the purpose of describing the historical growth, current sociolinguistic profile, roles and functions of English, the reasons for its significance regarding historical, social and cultural advancements along with the societal and individual attitudes towards English, and anti-English campaigns from different camps (Konig, 1990; Doğançay-Aktuna, 1998; Büyükkantarcıŏglu, 2004; Doğançay-Aktuna, \& Kızıltepe, 2005; Üzüm, 2007; e.g. Selvi, 2011).

Considering the fast-changing face of English, a current description of the position of English throughout Turkey is a pressing necessity. Therefore, I felt inclined to draw a critical analysis of the current place of English in Turkey, an expanding circle context (Kachru, 1992). However, while describing the place of English, I will pay special attention to language planning and policies, which will shed light on whether the current situation of English is an result of the planned or unplanned spread of English or if both phenomena play a part. This exploration will furthermore enable us to see whether English is perceived as a threat or on opportunity (e.g. linguistic capital) in the eyes of Turkish people from different walks of life.

\section{Country Profile}

Turkey is located on an area of 779, 452 sq. km which is approximately three times larger than the UK (242,514 sq. km). It serves as a bridge which connects the east to the west. Turkey is home to a number of ethnic groups within its bounds, the majority of whom are Turkish, the number of which corresponds to $81.33 \%$ of the population according to the statistics obtained in a study on how Turkish citizens perceived their ethnic identity (Milliyet Daily, 2007). The rest of the population comprises predominantly Kurdish, Arabic, Armenian, Greek and the other minorities. According to the Department of State (henceforth DP) “(m)ore than 70\% of Turkey's population lives in urban areas that juxtapose Western lifestyles with more traditional ways of life" (2012, emphasis added). The geographical location of Turkey together with her neighbors can be seen in Figure 1 below:

Turkish is the only official language of the state and used extensively as a lingua franca between the Turks and the minorities as well as among the minorities from different linguistic backgrounds (Doğançay-Aktuna, \& Kızlttepe, 2005). Therefore, it would be possible to state that Turkey is an officially monolingual state, as it is also firmly emphasized in article 3 of the current constitution, pronouncing that her official language is Turkish. 


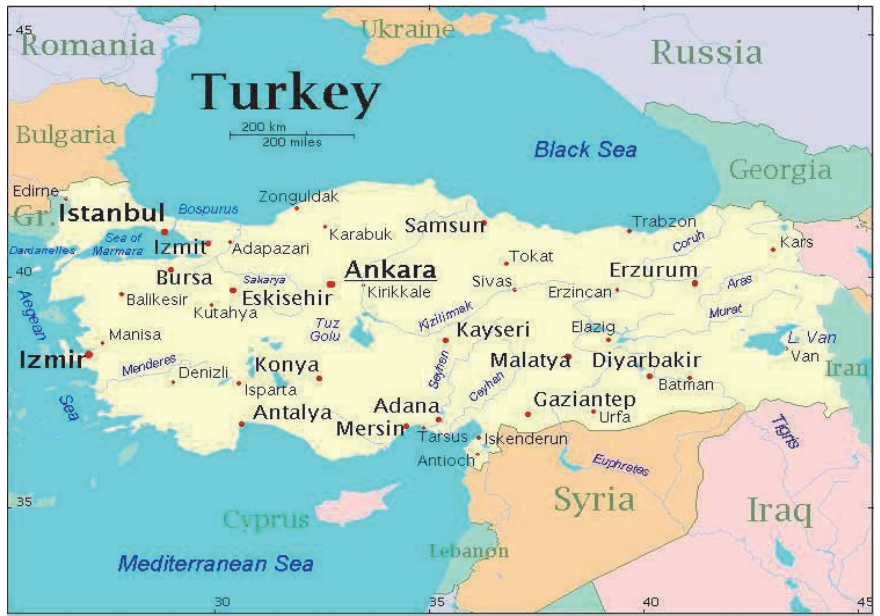

Fig. 1. Map of Turkey (http://pasinex.com/location/maps)
In respect of the socio-economic status of the country, till the 1980s, Turkey was defined as an underdeveloped, low-income country with comparatively few natural resources. Nevertheless, this status seems to be changing through a "transition from a high degree of reliance on agriculture and heavy industry to a more diversified economy with an increasingly large and globalized services sector" (DP, 2012). This transition has actually gained momentum due to the liberal economic policies and free market economy initiated in the 1980s by Turgut Özal, the $8^{\text {th }}$ President of the Turkish Republic (DoğançayAktuna, 1998; Doğançay-Aktuna, \& Kızıltepe, 2005). These policies brought about international bonds with other countries and made Turkey an open market for enterprise as well as letting Turkish investors and businessmen comfortably market their products in the international arena.

Turkey has been a member of NATO (The North Atlantic Treaty Organization) since 1952 and a candidate for the EU (European Union) since 1987. Turkey has also been an ally of the United States in the region for many years and their relations are based on a variety of areas ranging from trade and investment to energy cooperation and security ties against terrorism, to name a few. The orientation towards the West and western life and the strong relations with America might, therefore, be said to have created a welcoming atmosphere for English to spread at a great pace through Turkey, particularly since the 1950s. When the chronological development and relative importance of foreign languages in Turkey is considered, it is seen that English became a prominent foreign language, and since then it has magnified its existence gradually more and more throughout the country, overtaking and displacing other western languages such as French and German (Demircan, 1988; as cited in Doğançay-Aktuna, 1998). It is not surprising that the growth of English began to come towards a peak at a time when Turkey became a member of NATO, with establishing close ties with America.

\section{Conceptual Framework: Planned and Unplanned Language Spread}

Prior to drawing a broad picture of the omnipresence of the English language all over Turkey, I aim to elucidate the terms 'language spread' and 'planned and unplanned spread' to avoid terminological ambiguity while analyzing the impacts of the present-day expansion of English on various domains across Turkey. To start with, language spread, in its narrowest sense, is "[t]he phenomenon whereby uses or the users of a language increase" (Cooper, 1982, p. vii; emphasis in the original). However, in a broader sense, Cooper (1982) defines it as " $[a] n$ increase, over time, in the proportion of a communication network that adopts a given language or language variety for a given communicative function" (p. 6). Although some other definitions exist in the literature (see, for example, Lieberson, 1982), I will follow Cooper's (1982) definition throughout this study. The former definition might be accounted with a rough estimation that the number of users of English currently accounts for 800 million, nearly $57 \%$ of whom are composed of non-native users of English (Strevens, 1982, as cited in Kachru, 1992). Furthermore, it is also widely acknowledged that English has a large spectrum of uses 
comprising: politics, trade, science, education, industry, entertainment and such like spheres of international and global communication (Byram, 2000).

Both the planned and the unplanned spread of English are topics directly relevant to language planning, and this is, on the whole, steered by language planners and policy makers with an overt purpose although language spread is a process occurring repetitively in its nature (Kaplan, \& Baldauf, 1997). According to Doğançay-Aktuna (1998), the planned spread of any language relates to "the desired spread (acquisition) of the target language through education [at schools], because of its perceived advantages" via preferring it to the other alternative foreign languages (p. 29). Contrariwise, the unplanned spread of a language is unwished by the local authorities and often perceived as a threat owing to the perceived adverse and uncontrollable impacts of the spreading language upon the national language, lifestyle and culture of the nation (Doğançay-Aktuna, 1998; Büyükkantarcıoğlu, 2004). There is a common consensus that the unplanned spread of English is a by-product of not having clear-cut language planning policies within the state.

\section{The Current Place of English in Turkey}

The framework on which I will draw my analysis consists of four units, which are as follows: (1) English in Scientific Research and Communication; (2) English in the Workplace; (3) English through Cultural Products and the Media; (4) English in education. These four sections will be investigated in relation to the planned and unplanned spread of English in the remainder of this paper.

\section{English in Scientific Research and Communication}

English has come to play a role as a broadly utilized means of reaching, disseminating and storing scientific information all around the world. To quote from Crystal $(1997,106)$ " $[\mathrm{m}]$ ost of the scientific, technological and academic information in the world is expressed in English and over $80 \%$ of all the information stored in electronic retrieval systems is in English" and the largest databases are located in the USA (Truchot, 1997). The case in Turkey is no exception since many journals based in Turkey (e.g. E-Journal of New World Sciences Academy, Turkish Review, and the like) have also turned to publishing in English under English names, academics are compelled to write and publish in English through institutional and governmental policies. Some of them even use the word 'International' in their journal names to underscore that they address an international audience, and this is typically because they choose English as their language of publication. Oddly, although there is no empirical evidence, through visiting and having a glance at such journals' last volumes, it may be seen that the vast of majority of the writers are Turkish academics, but who write in English. In addition, it has been by far the most preferred language of international conferences so far held in Turkey irrespective of the small number or absence of native English speaking scholars in such conferences (Jenkins, 2011). Consequently, it would not be wrong to assert that English is also intra-nationally exploited in Turkey as far as science and research are concerned. And this use occurs in both modes of scientific and research activities: oral and written.

English is also a practical resource for Turkish academics from different fields of study areas in the workplace to benefit as a shared means of communication with their colleagues, with whom they do not share a common language. As demonstrated in a very recent study by Karakas (2012), Turkish academics extensively used English outside the inner circle contexts (contexts where English is officially used either as a first language or second language), and overwhelmingly with colleagues who are non-native English speakers, that is, in ELF (English 
as a lingua franca) situations where English served "as a contact language among speakers from different first languages" (Jenkins, 2009, 149) and they all pursued work-related goals while using English. Many academics who lack proper English knowledge resent the fact that they have to take English proficiency exams, and publish papers in internationally indexed papers to be able to reach the upper echelons of their profession (e.g. academic promotion, higher salary, money allowance). These requirements from academics lead to career tensions among those who lack a good working knowledge of English. However, academics who already graduated from English-medium universities or acquired the language earlier are more advantaged than those who studied in Turkish-medium universities. Güven's (2006) qualitative research with Turkish researchers from social sciences illustrate how some academics are concerned and feel less advantaged about publishing in English, as their fields do not lend themselves to publication in English. In this regard, one participant in Güven's (2006) research remarked that:

... to be able to remain in my current position in the university, I was asked to publish a paper in an internationally indexed journal. Although I told the administrators that the literature on the Turkish language in English is so scarce, and that journals would not be willing to publish such a study in English, they did not agree to my point. As a result of administrative pressure, I had to send my paper to an English-medium journal... their response was quite engrossing: "It is rather odd and striking to publish a paper on the structure of the Turkish language in ENGLISH (!)... (my translation and my emphasis)

The imposition of English on academicians through policies and by publishing houses from the initial step in academic life (e.g. application to an MA program) till the last stage (e.g. professorship) appears to be a part of planned language spread among Turkish researchers. However, these policies have not been welcomed by a great number of academics although they also deem English a noteworthy tool for their research and future career. This is because their promotion is heavily dependent on publishing in English-medium journals, which are indexed by highly prestigious databases. Failure to meet these criteria might cause them to be denied promotion. Another concern about the dominance of English in the Turkish scientific arena pertains to the issue that the role of Turkish in academia could play second fiddle to English as noted by Berg, Hult, and King, (2001; cited in Doğançay-Aktuna, 2005), which is considered by some Turkish intellectuals as a hindrance to the advancement of Turkish as a scientific language (e.g. Sinanoğlu, 2000; Gündoğan, 2010). To make this point much clearer, the following figure is presented to the reader so as to show how researchers reach larger audience when they resort to English as the language of their papers, and how those who publish, or engage in science in the national language (i.e. Turkish) perish in academia.

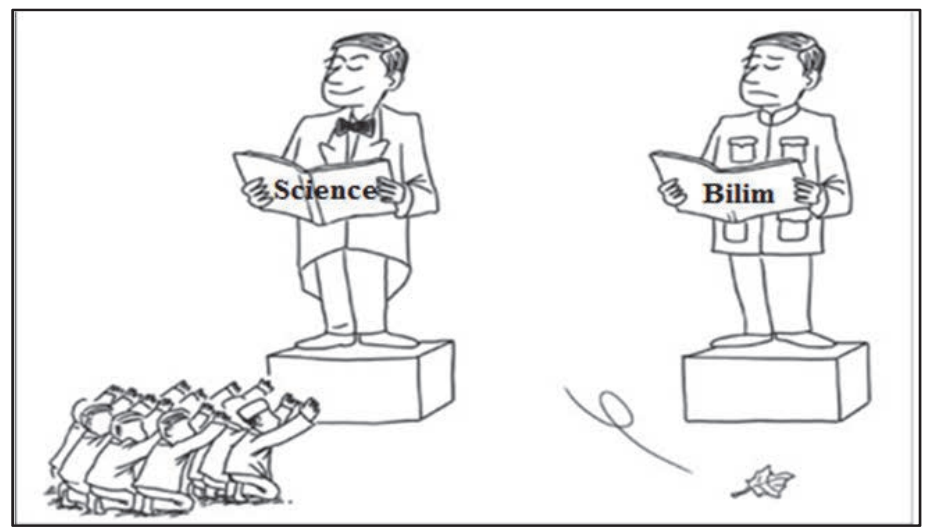

Fig. 2. Publish or perish mindset in Turkish academia (http://english.people.com.cn/90782/8004854.html) 


\section{English in the Workplace: Business, Industry and Public Sector}

English is being viewed by many non-native users as an essential asset to have which plays a crucial role on the way to getting a good job (McIntyre, 2009). Consequently, more and more Turkish people are struggling at least to learn a basic knowledge of English to move ahead especially financially and professionally, for "[i]t brings high status to the individual socially, as well as extending job opportunities" in many sectors, be it public or private business (Konig, 1990, 4; emphasis added). It should be noted at this juncture that the word 'business' is, within this paper, used as an umbrella term under which a number of sub-domains such as tourism, industry, trade and marketing, and the naming practices of stores can be covered.

The frequent use of and demand for English in companies is inevitable especially if they are operating in an international arena or involved in franchise business. This case is in tune with what Doğançay-Aktuna (1998) found in her investigation of job advertisements for different business branches in Turkey. Her findings revealed that knowledge of English was the leading job requirement and one-fifth of the advertisements were solely in English, which mainly aimed at eliminating those lacking knowledge of English. The job areas that necessitate English from job seekers were based on a set of sectors ranging from import-export and tourism to secretarial and administration jobs. This is a clear example of how "English acts as a gatekeeper for advancement in prestigious jobs" while leaving those lacking English knowledge in a disadvantaged position (Doğançay-Aktuna, 1998, 34).

The presence of English is at the most manifested to people from different strata of the society in the windows of the shops, stores along with their signboards as a result of naming practices (Selvi, 2011). To some, such a practice, essentially, "symbolises modernisation and elitism to the educated middle classes and those in the upper strata of the socioeconomic ladder" (Doğançay-Aktuna, 1998) and is likely to originate from the "recognition of the symbolic power of the English language" (Selvi, 2011, 196). Therefore, such practices of English apply less to the rural areas than urban environments where English is a necessity to vie for a job and go ahead in that job (Büyükkantarcioğlu, 2005). Especially in cities which are well-known as tourist attractions, one can feel as if she/he is wandering around in an English speaking country due to the bombardment of stores and shops' signs with English names as well as the advertisements written in English on the billboards. Since this sort of growth of English occurs out of control on the streets, it is a type of unplanned spread of English, which is seen by some scholars (e.g. language enthusiasts, columnists, politicians) as a threat to the linguistic, social, cultural and ethical values of the Turkish community.

As for the use of English in industry, it is limited to the regions where industrial companies are heavily located. These areas are, in Turkey, extensively sited in the western part of the country, geographically known as Marmara region. It is mostly practiced at the managerial level between the representatives of international companies (e.g. Renault, Toyota, Carrefour, McDonalds and so on) and their executive Turkish and non-Turkish staff to facilitate communication. Apart from at the managerial level, at the bottom level, English is not used or even not known by the workers. However, to train and educate qualified personnel according to the needs of the employers in several industry sectors such as metal techniques, electro-techniques and automotive to name a few, both industrial associations and educational institutions have started to work cooperatively. One example for this is the launch of the 'school-industry education project' (SIEP) which aims to create a qualified work force by meeting the need of personnel who are adequately and effectively trained, and who can follow the technology. Within the scope of the project, it is also aimed to train individuals who have foreign language skills and 
strong social aspects as well as professional development. To this end, English is allocated 5 hours per week within the program. As can be understood, the existence of English in industrial businesses is under the control of the authorities and highly desired for practical and instrumental purposes.

In the public sector, the basic knowledge of a foreign language (FL) is seen as a financial profit. When civil servants demonstrate a sufficient level of a FL based on the test scores taken from the Foreign Language Examination for Civil Servants (Yabancı Dil Sinavı [YDS]), they are granted extra bonuses (language allowance) to their monthly salaries for 5 years. English, according to the recent figures -May 2010- released by the Student Selection and Placement Center (Öğrenci Seçme ve Yerleştirme Merkezi [ÖSYM]) is by far the most preferred language in the exam: the total number of examinees equated to 96.857, of whom 91.524 opted to take the English language exam out of 23 foreign language options (ÖSYM, 2010). Such a high number in Selvi's (2011) words points to "The monopolistic status of the English language in Turkish context" among government employees (p.190). This is to be interpreted or seen as an overt and desired attempt by the government via financial incentives to equip its officials at least with the skills of a foreign language, predominantly English at this time.

\section{English through Cultural Products and the Media}

Even laypeople are no longer unfamiliar with English since they are in a constant contact with it due to popular culture, imported products and the media. Otherwise stated, English has even penetrated into bedrooms, the most intimate place of the Turks. This type of intrusion of English into daily and private life has occurred and continues to occur through imported American cultural goods and products such as movies, literature, music, advertising campaigns, food (e.g. restaurant chains like McDonalds), TV programs and shows, electronic games and so on. In this regard, Rohde (2003) clearly points out the power of media and the Internet by saying that, "[w] hat centuries of British colonialism and decades of Esperanto couldn't do, a few years of free trade [since 1980s in Turkey], MTV, and the Internet has" done in a relatively short time. For instance, some non-Turkish phrases transferred into Turkish through TV series as a result of the dubbing practice have started to be adopted by the younger generation (Öniz, 1997). They joyfully mix such English words in their exchanges of conversation among their peer groups, as a sign of how fashionable and trendy they are.

The movies and other visual and aural programs imported from English speaking countries generally do not reach all Turkish viewers in the original language. The prevailing tendency is to broadcast them by dubbing into Turkish. However, there are some TV channels that transmit their programs in English subtitled with Turkish (e.g. TNT, CNBC-E, E2). Also, since the 1980s, the number of private channels has tremendously increased due to privatization movements which ended the dominance and strict control of the Turkish Radio and Television Supreme Council (TRT) over the media, a governmental body which followed highly controlled broadcasting policies across the country prior to the privatization process (Büyükkantarcıoğlu, 2004). Many private broadcasting companies, be they TV channels (e.g. Star, Flash, Fox, Show TV, NTV, CNN Türk, Cine5) or radio stations (e.g. Super, Power, Number 1, Best, Metro FM, Joy TURK, Fenomen), have taken English names, even though most of them do not air their programs in English.

In addition to the audio-visual media, Turkey has witnessed considerable changes in the printed media starting to print fully English newspapers. Turkey had its first English Daily in 1961 under the name 'Turkish Daily News' which was later renamed Hürriyet Daily News in 2008. Following the Turkish Daily News, the second English daily came into existence in 1982 
with the name 'Made in Turkey'. The other two English-medium newspapers, The New Anatolian and Today's Zaman, have also become available at newsstands since 2005. However, their weekly circulations, as pointed out by Selvi (2011), is relatively small, fewer than 10.000 . Some daily newspapers printed only in Turkish offer an online English version to their Turkish and non-Turkish readers. In addition to these dailies circulated country-wide, there are some local Turkish dailies printed in English, and they can be found mostly in tourism and recreation areas where thousands of tourists from all over the world are flocking especially in summer. These dailies include Anatolian News (Bursa), Didim Today (Didim, Altınkum, Akbük Aydın), The Didymian (Didim-Aydın), Good Morning Turkey, Kalkan News (Kalkan, Kaş Antalya). It is obvious that these dailies are printed to address the tourists rather than the local Turkish people. However, there are currently no figures in relation to their weekly circulation. The most widely circulated three dailies are given below in Figure 3:
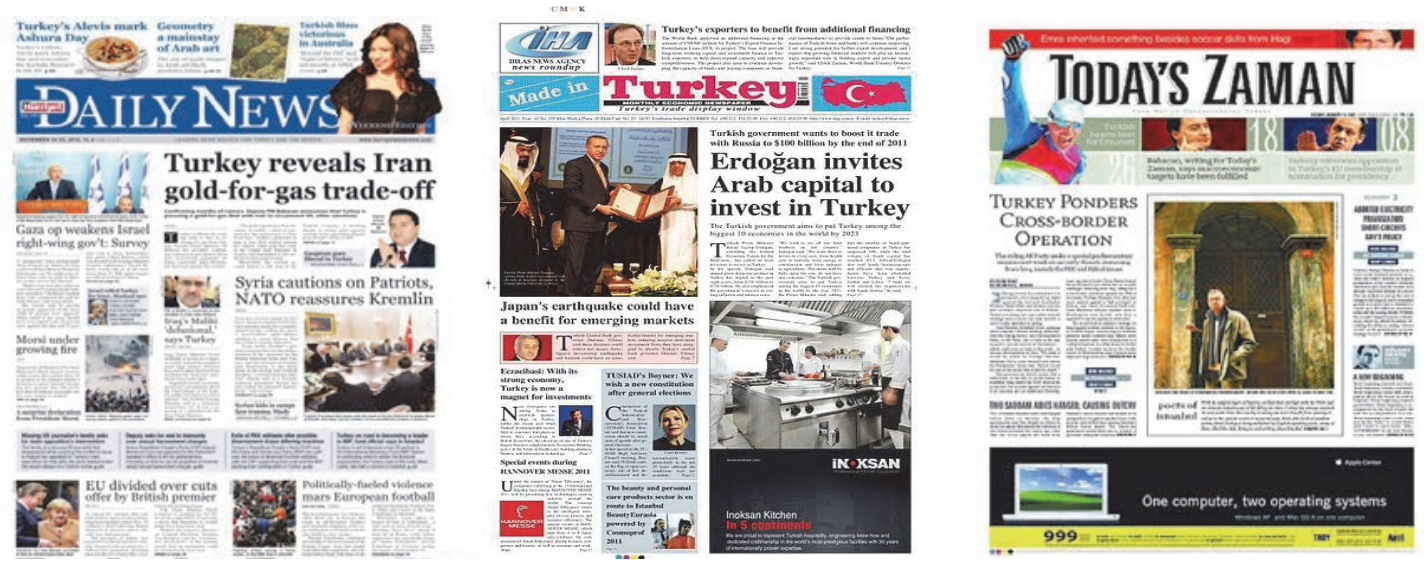

Fig. 3. Turkey's most widely distributed English dailies.

The impact of social media on the popularity of English among Turkish people particularly the younger generation have remarkably remained under explored in previous studies. Considering the wide range of examples of social media such as social news (e.g. Propeller), networking (e.g. Facebook, Hi5), photo and video sharing (e.g. YouTube, Flickr) and finally wikis to name but a few. For these types of social media, the users generally prefer English over other languages, which comes as no surprise given that "English continues to be the chief lingua franca of the Internet" (Crystal, 2003, 117). As a result of engaging with the Internet, especially the young talk about 'tweeting', 'tagging', 'sharing', 'poking', 'liking' among many others, since the use of such words is a means to show off and to emulate the western way of life.

For some people ranging from columnists to academicians, the infiltration of English words into the Turkish lexis either directly or in a modified way is a detrimental but natural consequence of the above mentioned fluctuations. The growing number of borrowings from English, even though Turkish has the equivalent words in its lexicon, creates anxiety among some people loyal to their national language, as the influx of English vocabulary is hard to control. It is on occasion springing up as a result of the unplanned spread of English. To some, as marked by Rohde (2003) "English is taking more than it is giving" and many Turks share this concern to a large extent. In a similar vein, Phillipson (1992) argues that cultural activities and imports such as movies, televisions, videos, brand names frequently foist English linguistic imperialism on other languages. He also links the boost of English chiefly to media imperialism, business and policies, which inadvertently aid the entry of English words into Turkish life by revealing itself on the buses, in the trains, at the stations, on shop windows, on the store signs 
and the like. Bothered by these practices, a political party, Milliyetçi Hareket Partisi (Nationalist Movement Party) took a bold step to ban the use of foreign words in advertisements and announcements with the development of a legislative proposal in order to purify Turkish from the influences of foreign languages [English primarily] and this initiative came to be known as the 'Turkish Signboard Attack' with the intention of enlivening a former law in operation till 1980 entailing advertisements and announcements to be only in Turkish (Bilgin, 2000). However, their attempts ended in failure since only a few municipalities (e.g. Esenler Municipality) paid attention to their proposed bill. The failure of such an effort can be neatly explained in the words of Wardhaugh $(1987,16)$.

Most language spread is unplanned and this may still be largely the case when states directly involve themselves in language matters, for example, in language planning activities. Many of the factors affecting what happens to this language or that may be well beyond the control of all but the most wealthy and/or autocratic governments. Laws may be passed, sanctions may be employed, and various agencies and reinforcing systems may be established. However, ... a spreading language seems to have a dynamic all of its own and many such moves may do little or nothing to alter that dynamic (as quoted in DoğançayAktuna, 1998, 29).

\section{English in Education}

English is the most popular and preferred language, and the second medium of instruction at various educational levels starting from the primary schools to universities. It is learned by $98.4 \%$ of the students followed by German and French learners who constitute $1.6 \%$ of the student population (Genç, 1999; cited in Selvi, 2011). The teaching of English is supported through educational policies to get every educated Turkish citizen to have at least a working knowledge of English. Institutions aiming to teach English across the country fall into two categories: state-run institutions and private institutions. They differ from each other in many terms such as the medium of instructions, preference for teachers (native-speakers to Turkish), selection of materials, and the age to start learning English among many others.

In state schools, students start to take English classes at the age of 11-12 ( $4^{\text {th }}$ grade). Yet, in private schools, teaching of English starts from kindergarten and usually English is opted as the medium of instruction. Therefore, it would not be wrong to say that those attending private schools develop their English far better in terms of each single skill while those in resource poor environments, at state schools remain less proficient. For the level of high school, the hours of teaching differ from one school to another, for there are a great many of types of high schools ranging from general high schools to vocational high schools. Vocational schools specifically attach importance and time to vocational English classes in their curricula while high schools aim to equip students with a basic knowledge of English.

Universities also offer compulsory English classes to their students in the first year of their program. In Turkish medium universities, in the first year, students have to take two-hour English classes per week. However, in English medium universities, students have to take an English proficiency exam before they can start their first year in their degree programs. Unless they get an admissible test score, the regulations presuppose such students take one year intensive English classes, which are widely known as "preparatory classes" during which students are reinforced in terms of specific language skills. Those successfully completing their 
prep year are given the right to start their first year. Many Turkish medium universities have also adopted this one-year-intensive English policy with the purpose of improving the language proficiency of the students who are believed to come with poor linguistic knowledge and cannot use language properly and functionally to meet their needs.

Not everyone sees, however, the adoption of English as the medium of instruction and offering one-year intensive English to students as a benign or even a necessary phenomenon. Many deem that such policies cause damage to the education and to the future of the country (Demircan, 2006) and consider that they pose a threat to the advancement of the Turkish community, its language and culture in the world arena that might result in a worst case of cultural deterioration and even worse loss in the end (Selvi, 2007). Similarly, Sarıçoban and Sarıçoban (2012), in their paper on 'Atatürk and the History of Foreign Language Education in Turkey', underscore the fact that even Atatürk, the founder of the Turkish republic, was against teaching content courses in a foreign language, but he was a strong supporter of teaching not a foreign language but foreign languages. They further conclude that as the schools, particularly higher education institutions have increasingly turned to a foreign language which euphemistically refers to English in Turkey, we are confronted with an unpleasant situation in which Turkish, the national language, has lost its significance. Moreover, attitudinal data revealed that Turkish academics prefer Turkish as the medium of language rather than English, claiming that the level of acquisition of subject knowledge decreases when students are taught in English (Kılıçkaya, 2006).

On the other hand, those who favor such implementations assert that the knowledge of the world lingua franca is an all-important quality to have for each Turkish citizen in the $21^{\text {st }}$ century, and from a bilingual perspective; it fortifies the students' mental and linguistic capabilities, and improves their cross-cultural, intellectual and language skills (Alptekin, 1989, 2003; Soylu, 2003). This blurry picture brings us to the conclusion that the planned spread of English through education does not arouse similar responses from different camps, since their points of view stem from different perceptions. This is not because those who feel anxious about the negative influence exerted by English do not value English. Rather, they also appraise the practical utilities of English. What they are worried about is the policies implemented by governmental bodies such as universities, associations from English speaking countries such as British and American Cultural Associations, the British Council and the like. In Phillipson's (1992) words, for example, the British Council operates "as a key for nurturing the teaching of English worldwide", dedicating itself to "the promotion of English, with government, academic, and commercial interests" (p. 37) at the expense of national languages. Despite such apprehensions, attitudinal studies indicate that both students and parents favor English-medium secondary and higher education due to the instrumental profits English brings with it (e.g. Tarhan, 2003; Çiftçi, \& Deniz, 2010).

\section{Conclusions}

The current study has dealt with the position of English in Turkey drawing a descriptive picture of its presence in a number of domains, with critical evaluation of the policies to promote English in a controlled way, and of the perceived threats posed by the unplanned spread and often undesirable penetration of English into Turkish life primarily via different sorts of media and business practices. In what follows, I turn my attention to the major conclusions to be drawn from this exploration of the place of English in Turkey.

First and foremost, English is diffused across the state primarily and desirably with educational policies and unappealingly as an upshot of globalization and internationalization, both 
of which exert excessive influence on trade, industry, tourism and media and such other domains where the use of English is initially intended for international communication. In other words, its use takes place in transglossic situations once it is used for activities that include speakers of different languages (Truchot, 1997). However, such situations mostly occur beyond the boundaries of the state, when Turkish citizens travel to other countries for different goals (e.g. commerce, tourism, conferences) and use English as a lingua franca.

Although English enjoys almost no official status with the exception of its use as the medium of language in some universities, and is not used as a means of communication among Turkish citizens and the minorities residing within the country, the recent situation has started to change due to the mushroom-like growth of English as a medium of discourse primarily in private and also in state institutions, from primary to higher education. This has given birth to the characteristics of the former colonies of English speaking countries emerging in Turkey via educational policies by the state at the cost of the national language (Selvi, 2011) though Turkey has never been subject to any colonization in its past. Konig (1990) criticizes these policies by arguing that such practices are not even extant in colonies today. He further adds that while other countries (e.g. France, Spain) strive to keep English away from their internal affairs and domains and promote it for international communication, Turkey has exactly done the opposite by giving permission for the penetration of English in education, media, and window displays of the shops, etc. According to Phillipson (1992, 137), this is another form of "new international crusade" that comes from internal sources rather than from outside attacks.

Overall, the analysis brings us to a point where "we have been facing the dilemma of how to expand the planned spread of English in Turkey while suppressing its unplanned spread, with no easy solution in the horizon" (Doğançay-Aktuna, 1998, 30). Regarding this problem, she also raises some suggestions such as "careful language planning and educational policy making" and most importantly "mother tongue awareness in Turkish people" (p. 38) in order to cope with such dilemmas. However, it is worth stressing here that while developing mother tongue awareness, the significance of English as a lingua franca and international language should not be mitigated, but conveyed to the people, as other European countries have done, for international communication and instrumental gains, in order to keep them motivated and enthusiastic to learn it.

In conclusion, regarding the question as to whether English poses a threat or brings opportunities to Turkish people and the Turkish language, it might be rightly said that there is not a straightforward answer. One reason for this lack of proper answers is that not everyone can benefit from the language on an equal footing, or at the same level, and their approach to English originates from different viewpoints. To summarize, it is by and large educationalist, columnists, language loyalists, viz. people nearest the top of society, who have deep concerns as regards the spread of English. On the flip side of the society, individuals such as parents, laypeople, students, employer, and central authorities do not care much about the ubiquity of English, but have high regard for the potential paybacks of having English knowledge. In this connexion, if Ostler's (2010) speculation that the English language will lose its current dominance as the global lingua franca such as Latin and Sanskrit did sees the light of day, then there is no need to be worried about the issue of English in Turkey. However, only time will tell us whether such a pessimistic prediction will come true or not. For the time being, however, such a prediction seems to be just an illusion, and English seems to resist fading away so easily not only in Turkey but around the world. Consequently, the case for English appears to continue to be contestable in the years to come. 


\section{REFERENCES}

Alptekin, C. (1989). “Yabancı Dil Ögrenmek Türkce’yi Unutturmaz”. (Learning a foreign language does not mean the loss of Turkish language). Ed. Ayse Kilimci. Anadilinde Cocuk Olmak: Yabancı Dilde Egitim, 34-7, (To Be a Child in Mother Tongue: Education in Foreign Language). İstanbul: Papirus Yayınevi.

Alptekin, C. (2003). “English-medium Education and Quality Assurance in a Turkish State University”. Retrieved from http://www.unimaas.nl/icl/abstracts_t1_Alptekin.htm

Berg, C. E., Hult, F. M. \& King. A. (2001). “Shaping the climate for language shift? English in Sweden’s elite domains”. World Englishes, 20, (3), 305-19.

Bilgin, N. (2000). MHP’den Türkçe Tabela Atağı, (Turkish Signboard Attack by MHP). Sabah Daily, 22 October. Retrieved from http://arsiv.sabah.com.tr/2000/10/22/p01.html

Byram, M. (2000). Routledge Encylopedia of Language Teaching and Learning. London: Routledge.

Büyükkantarcıoğlu, N. (2004) "Sociolinguistic analysis of English in Turkey”. International Journal of Sociology of Language, 165, 5-32.

Cooper, R. L. (1982). “A Framework for the Description of Language Spread”. Ed. R. L. Cooper. In Language Spread: Studies in Diffusion and Social Change, 5-36. Bloomington: Indiana University Press.

Crystal, D. (1997). English as a Global Language. Cambridge: Cambridge University Press.

Crystal, D. (2003). English as a Global language. (2 ${ }^{\text {nd }}$ ed.) Cambridge: Cambridge University Press.

Çiftçi, H. \& Deniz, S. (2010). “Turkish Students’ Attitudes towards the English Language at the Metu Sociology Department”. StudyMode.com. Retrieved from http://www.studymode.com/essays/ Turkish-Students-Attitudes-Towards-The-English-1138276.html.

Demircan, O. (2006). “Öğrenci Açısından Yabancı Dil Öğretimi ile Yabancı Dilde Öğretim İlişkisi”, (The relationship between foreign language education and foreign-medium education from the learner's point of view). Paper presented at Language and Communication Society meeting, November at Yıldız Technical University, Istanbul, Turkey.

Doğançay-Aktuna, S. (1998). "The Spread of English in Turkey And its Current Sociolinguistic Profile”. Journal of Multilingual and Multicultural Development, 19, 24-39.

Doğançay-Aktuna, S. (2004). “Language Planning in Turkey: Yesterday and Today”. International Journal of Sociology of Language, 165, 5-32.

Doğançay-Aktuna, S. \& Kızıltepe, Z. (2005). “English in Turkey”. World Englishes 24, 253-65.

Genç, A. (1999). “İlkögretimde Yabancı Dil”, (Foreign Language in Primary Education). Buca Eğitim Fakültesi Dergisi, 10, 299-307.

Gündoğan, A. O. (2010). "Bilim Dili Olarak Türkçe”, (Turkish as the language of Science). Atatürk Üniversitesi Türkiyat Araştırmaları Enstitüsü Dergisi, 7-12. Retrieved from http://e-dergi.atauni. edu.tr/index.php/taed/article/viewFile/1936/1942.

Güven, İ. (2006). "Yurtdışı Sosyal Bilimler Dergilerinde Yayın Süreci”. Ankara Üniversitesi Eğitim Bilimleri Fakültesi, Sosyal Bilimlerde Süreli Yayıncılık I. Ulusal Kurultay Bildirileri.

Jenkins J. (2009). World Englishes. A resource book for students (2nd ed). London: Routledge.

Jenkins, J. (2011). “Accommodating (to) ELF in the International University”. Journal of Pragmatics, 43, (4), 926-936.

Kachru, B. B. (1992). “Models for non-native Englishes”. Ed. in Braj B. Kachru. The Other Tongue: English Across Cultures, 48-74. Urbana, IL: University of Illinois Press.

Kaplan, R. B., \& Baldauf, R. B. Jr. (1997). Language Planning from Practice to Theory. Clevedon: Multilingual Matters.

Karakaş, A. (2012). “English as a Lingua Franca: Practices of Academics in a Turkish University”. Paper presented at the Fifth International Conference of English as a Lingua Franca. May 24-26, 2012. Bogazici University, Istanbul-Türkiye.

Kılıçkaya, F. (2006). “Instructors’ Attitudes towards English-Medium Education in Turkey”. Humanizing 
Language Teaching, 8, (6), 1-9. Retrieved from http://www.hltmag.co.uk/nov06/mart01.htm.

Konig, G. (1990). “The place of English in Turkey”. Ed. Deniz Bozer. The Birth and Growth of a Department: Department of English Language and Literature: 25 ${ }^{\text {th }}$ Anniversary, 157-67. Ankara: Hacettepe University.

Lieberson, S. (1982). Forces Affecting Language Spread: Some Basic Propositions. Language Spread: Studies in Diffusion and Social Change, 37-62. Ed. Robert L. Cooper. Bloomington, Indiana: Indiana University Press.

McIntyre, D. (2009). History of English: A Resource Book. London and New York: Routledge.

Milliyet Daily (March, 2007). “53 Milyon Kisi Etnik Olarak Turk”, (53 Million People Are ethnically Turkish). Retrieved from http://www.milliyet.com.tr/2007/03/22/guncel/agun.html.

Ostler, N. (2010). The last lingua Franca: English until the Return of Babel. Bloomsbury Publishing USA.

Öniz, S. (1997). “Mini Survey on Whether Soap-Opera-English has Found its Way into Turkish”. Eds. Sibel Tüzel Köymen, \& Bülent Kandiller. Perspectives in English Language Teaching: Proceedings of the 4th METU ELT Convention, 254-69. Ankara, Department of Basic English, School of Foreign Languages, Middle East Technical University, 1997.

ÖSYM (2010) 2010-KPDS İlkbahar Dönemi Sayısal Bilgiler. (2010-KPDS Spring Session: Statistical Information). Retrieved from http://www.osym.gov.tr/dosya/153061/h/kpdssayisalbilgiler201001.pdf

Phillipson, R. (1992). Linguistic Imperialism. Oxford: Oxford University Press.

Rohde. D. (2003). “As English spreads, Speakers Morph it into World Tongue”. Christian Science Monitor. Retrieved from www.pbs.org/speak/ahead/globalamerican/global/

Sarıçoban, G. \& Sarıçoban, A. (2012). “Atatürk and the History of Foreign Language Education”. The Journal of Language and Linguistic Studies, 8 (1), 24-49.

Sinanoğlu, O. (2000). Bye Bye Türkce: Bir New York Rüyası, (Bye Bye Turkish: A New York Dream). İstanbul: Otopsi Yayınları.

Selvi, A. F. (2007). A Multifactorial Sociolinguistic Analysis of Business Naming Practices in Turkey. Unpublished Master's thesis, Middle East Technical University, Ankara.

Selvi, A. F. (2011). "World Englishes in the Turkish Sociolinguistic Context”. World Englishes, 30 (2), 182-189.

Soylu, E. (2003). Multiple intelligences in content-based instruction: how and to what extent could MI theory be used to facilitate learning in CBI? Retrieved from http://www.unimaas.nl/icl/abstracts_t7_ Soylu.htm

Strevens, P. (1982). "World English and the World's Englishes; or, Whose Language is it, Anyway?" Journal of the Royal Society of Arts, 120/5311, 418-431.

Tarhan, Ş. (2003). Perceptions of Students, Teachers and Parents Regarding English Medium Education at Secondary Education. Unpublished Doctoral Dissertation, Middle East Technical University, Ankara, Turkey.

Truchot, C. (1997). “The Spread of English: from France to a More General Perspective”. World Englishes, $16(1), 65-76$.

U.S. Department of State (March, 2012). Background Note: Turkey, Retrieved form http://www.state. gov/r/pa/ei/bgn/3432.htm

Üzüm, B. (2007). An Investigation of Turkish Learners 'Attitudes Towards English and English-speaking Societies. Unpublished Master’s thesis, Middle East Technical University, Ankara.

Wardhaugh, R. (1987). Languages in Competition: Dominance, Diversity, and Decline. Oxford: Basil Blackwell. 